\title{
Patients with primary hyperparathyroidism undergoing surgical intervention in two tertiary care hospitals in Sri Lanka
}

\author{
Mohamed RS 1 , Abeynayake RPSN², Manathunga R², 3, Samarasekara T³, Antonypillai CN1 \\ Department of Diabetes and Endocrinology, Teaching Hospital Kandy ${ }^{1}$, Department Of Oncological Surgery Teaching Hospital \\ $K_{\text {Kandy }}^{2}$, Diabetes and endocrine unit, Provincial General Hospital Badulla ${ }^{3}$
}

Copyright: This is an open-access article distributed under the terms of the Creative Commons Attribution License, which permits unrestricted use, distribution, and reproduction in any medium, provided the original author and source are credited (CC BY 4.0)

\section{Introduction}

Autonomous production of parathyroid hormone results in primary hyperparathyroidism. Sri Lankan studies analyzing cases of hyperparathyroidism are scarce.

\section{Objective}

To describe clinical, biochemical, radiological and pathological characteristics of patients with primary hyperparathyroidism undergoing surgical intervention in two tertiary care hospitals in Sri Lanka.

\section{Design}

Data was collected from the available records of all patients who has undergone surgery for primary hyperparathyroidism at Teaching Hospital, Kandy and General Hospital, Badulla from 2016.10.27 to date. A total of ten patients with primary hyperparathyroidism were enrolled for analysis. Out of the ten patients, six were females. Ages ranged from 23 to 65 years (Mean- 44.2). Mode of presentation was fragility fractures in four patients, renal calculi in five patients and acute pancreatitis in one patient. Bone complications (fractures, osteoporosis) were seen in four patients and renal complications (renal calculi, nephrocalcinosis) were seen in six patients. Pre-operative total serum calcium levels ranged from 10.52 to $14.16 \mathrm{mg} / \mathrm{dl}$ (mean-12.6). Pre-operative serum phosphate levels ranged from 0.74 to $1.07 \mathrm{mmol} / \mathrm{L}$ (mean -0.868 ).

$\mathrm{X}$-ray evidence of skeletal changes of hands were seen in 6 patients $(60 \%)$, of which 4 showed bony deformities and 2 showed pathological fractures. Renal calculi or nephrocalcinosis was detected by X-ray in five out of six patients and ultrasonically in all 6 patients. Ultrasound scans revealed a parathyroid adenoma in 8 patients $(80 \%)$, while 2 were negative. Technetium-99-methoxyisonitrile (99m Tc-Sestamibi) scans were performed in 4 patients and three had positive images. Histological analysis revealed 8 patients with single parathyroid adenoma, 1 with parathyroid carcinoma, and one patient with four gland hyperplasia.

\section{Discussion and Conclusions}

All patients had symptoms at the time of diagnosis. Ultrasound scan was a useful tool for the localization. 


\section{Introduction}

Primary hyperparathyroidism is one of the commonest endocrinological diseases in the developed world with the prevalence of 50 per 100,000 population. Around $80 \%$ of them have asymptomatic primary hyperparathyroidism(1),(2). However, there is sparse description of this common disorder in our part of the world.

\section{Objective}

\section{General Objectives}

To describe characteristics of primary hyper parathyroid patients undergoing surgical intervention in two tertiary care hospitals in Sri Lanka (Teaching Hospital Kandy and District General Hospital, Badulla, Sri Lanka)

\section{Specific Objectives}

To describe clinical, biochemical, radiological and pathological characteristics of them.

\section{Methodology}

Prospectively data was collected from patients' records of all primary hyperparathyroid patients who underwent surgery at Teaching Hospital, Kandy and General Hospital, Badulla from 2016.10.27 to date. Patients' clinical features, biochemical and imaging findings, surgical procedures and histological findings were collected.

\section{Statistical Analysis}

Statistical analysis was done with Epiinfo version:7.2.2.6. Means and range of age, total corrected Calcium, phosphate, serum PTH and parathyoroid gland size were done. Sensitivity and specificity of the ultrasound scan imaging of the parathyroid gland was analysed.

\section{Results}

Out of the10 patients, 6 were females. Ages ranged from 23 to 65 years (Mean-44.2). Triggers for the evaluation for primary hyperparathyroidism were, fragility factures or bony deformities in 4 patients, renal calculi in 5 patients and acute pancreatitis in one patient (Table 1). The initial total serum calcium level ranged from 10.52 to 14.16 $\mathrm{mg} / \mathrm{dl}$ (mean-12.6) and serum phosphate level ranged from 0.74 to $1.07 \mathrm{mmol} / \mathrm{L}$ (mean -0.868). (Laboratory Calcium and phosphate reference ranges were $8.4 \mathrm{mg} / \mathrm{dl}$ to $10.2 \mathrm{mg} / \mathrm{dl}$ and 0.81 to $1.45 \mathrm{mmol} / 1$ respectively). Average parathyroid hormone level (Normal PTH level -6-80) was $1306 \mathrm{pg} / \mathrm{ml}$ for parathyroid adenomas (ranged from 340 to $1849), 1082 \mathrm{pg} / \mathrm{ml}$ for the only parathyroid carcinoma and $212 \mathrm{pg} / \mathrm{ml}$ for multi gland disease(Table 2). Dual-energy X-ray absorptiometry (DXA) scans were performed in 5 patients, of which 4 had osteoporosis (mean bone mineral density BMD -0.498) and one had osteopaenia (BMD $0.826)$.

\section{Table 1. Mode of presentation for primary hyperparathyroidism}

\begin{tabular}{lc}
\hline Triggers for the evaluation & Number of patients \\
\hline Fragility fracture or bony deformity & 4 \\
Renal calculi & 5 \\
Acute pancreatitis & 1 \\
Total & 10 \\
\hline
\end{tabular}


Table 2. Biochemical Characteristics of primary hyperparathyroidism

\begin{tabular}{lll}
\hline & Mean & Range \\
\hline Total corrected Ca & $12.64 \mathrm{mg} / \mathrm{dl}$ & $10.52-14.16$ \\
Phosphate & $0.87 \mathrm{mmol} / 1$ & $0.74-1.07$ \\
PTH (Parathyroid adenoma) & $1306 \mathrm{pg} / \mathrm{ml}$ & $340-1849$ \\
PTH (Parathyroid carcinoma) & $1082 \mathrm{pg} / \mathrm{ml}$ & \\
PTH (Parathyroid hyperplasia) & $212 \mathrm{pg} / \mathrm{ml}$ & \\
\hline
\end{tabular}

All patients underwent ultrasound scan of the parathyroid glands and it identified a parathyroid tumour in 8 patients (Table 3). Although in one patient' ultrasound was suggestive of a thyroid nodule, subsequent CT scan reported the corresponding lesion as a possible parathyroid tumor. Finally, it turned out to be a parathyroid carcinoma. The second person who had a negative ultrasound scan underwent $99 \mathrm{~m}$ Tc-Sestamibi and it was also negative. Four patients underwent $99 \mathrm{~m}$ TcSestamibi including the above mentioned patient. In the remaining three patients it identified a parathyroid tumour.

\section{Table 3. Imaging findings in patients with primary hyperparathyroidism}

\begin{tabular}{|c|c|c|c|c|c|}
\hline Patient No. & USS Neck & CECT & Tc99m Sestamibi scan & Surgery & Histology \\
\hline $1-8$ & Parathyroid adenoma & Not done & $\begin{array}{l}\text { Parathyroid } \\
\text { adenoma }(\mathrm{n}=3)\end{array}$ & $\begin{array}{l}\text { Selective } \\
\text { parathyroidectomy }\end{array}$ & $\begin{array}{l}\text { Parathyroid } \\
\text { adenoma }\end{array}$ \\
\hline 9 & $\begin{array}{l}\text { Only thyroid nodule } \\
\text { seen }\end{array}$ & $\begin{array}{l}\text { Parathyroid adenoma } \\
\text { corresponding to USS lesion }\end{array}$ & Not done & $\begin{array}{l}\text { Selective } \\
\text { parathyroidectomy }\end{array}$ & $\begin{array}{l}\text { Parathyroid } \\
\text { carcinoma }\end{array}$ \\
\hline 10 & $\begin{array}{l}\text { No abnormality } \\
\text { detected }\end{array}$ & Not done & $\begin{array}{l}\text { No abnormality } \\
\text { detected }\end{array}$ & $\begin{array}{l}21 / 2 \text { parathyroid glands } \\
\text { removed }\end{array}$ & $\begin{array}{l}\text { Parathyroid } \\
\text { hyperplasia }\end{array}$ \\
\hline
\end{tabular}


During surgery the location of the enlarged parathyroid gland was concordant with the ultrasound scan, CT scan and Tc99Sestamibi findings. In the patient who had negative ultrasound scan and $99 \mathrm{~m}$ Tc-Sestamibi, only 3 parathyroid glands were identified during surgery. Patients who had positive localization with ultrasound scan and technetium scan had a parathyroid adenoma at surgery and they were cured postoperatively. The one who had negative ultrasound with localization by CT scan had parathyroid carcinoma without evidence of metastasis. The one who had negative ultrasound scan and sestamibi scan, only three glands were identified and removed but he was not cured postoperatively. Finally the remaining gland was localized by parathyroid venous sampling. Repeat surgery detected remaining right upper parathyroid gland.

Histological evaluation of the surgical specimen showed single parathyroid adenoma in eight patients, parathyroid carcinoma in one and four gland hyperplasia in one who had initial negative ultrasound and $99 \mathrm{~m}$ Tc-Sestamibi.

\section{Discussion}

Clinical and biochemical features of patients who underwent parathyroid surgery presented in recent Western literature were as follows: majority of the cases occurred over the age of 50-65 years and majority of them were women ${ }^{(3),(4)}$. Asymptomatic primary hyperparathyroidism was seen in $80 \%$ of cases. Average serum Calcium was $10.8 \pm 0.1 \mathrm{mg} / \mathrm{dl}$, Serum PTH level 144 $\mathrm{pg} / \mathrm{ml}$, renal stones accounted for $15 \%$ of cases, average lumbar BMD Z score $-0.8 \pm 0.2$ and sensitivity and specificity of USS imaging was $42-82 \%$ and approximately $90 \%$ respectively $(1),(5)$. Average weight of the parathyroid adenoma was $1 \mathrm{~g}$ (normal gland weighs $50 \mathrm{mg})^{(6)}$. However, in our cohort all patients were symptomatic. It had higher mean Calcium value and Serum PTH value. Out of the patients whoever underwent DXA (N=5),four had osteoporosis and one had osteopenia. Sensitivity and specificity of USS on localization were $89 \%$ and $100 \%$ respectively.

An article published in Lancet in 1980 describes changing pattern of presentation over time. It shows that in earlier studies majority of them were symptomatic at the time of presentation. Symptoms were mainly attributed to renal stones, nephrocalcinosis and bone disease as in our series.
However during the 1980 s, majority of the patients $(57 \%)$ were asymptomatic probably due to routine measurement of Calcium(7).

Our data suggests that the Sri Lankan picture of patients who presented with hyperparathyroidism is similar to what was seen in the Western hemisphere before 1980. There are several possibilities for this scenario. Only recently serum Calcium became widely available in Sri Lanka and PTH assays are still limited to a few centres. Although facilities for Serum Calcium measurement is freely available now, it is not routinely requested by clinicians. Lack of awareness among health care professionals regarding this common endocrinological disorder is also an important factor. As a result all patients were symptomatic at presentation and none had normocalcaemic hyperparathyroidism despite vitamin D deficiency being prevalent in this country ${ }^{(8)}$.A population based study done at Rochester, Minnesota in between 1965-1992 suggested that routine measurement of serum Calcium led to a sharp increase in the incidence of primary hyperparathyroidism(2). So in our country also there should be a rise in incidence in upcoming years due to increased availability of Serum Calcium measurement. We are planning to recruit and follow-up more primary hyperparathyroid patients during upcoming years.

Ultrasound scan had more sensitivity in our series compared to the data in Western literature. Although there is no explanation for this, late presentation among our patients may be a reasonable postulation that needs to be investigated further.

\section{Conclusion}

Although majority of the patients with primary hyperparathyroidism in the Western world are asymptomatic at the time of diagnosis, in our small case series all had symptoms at the time of presentation. It suggests that more awareness is required among medical practitioners to diagnose this condition early.

Ultrasound scan is a cheap, readily available and less invasive investigation in localizing parathyroid adenoma in resource poor settings. In the hands of good sonographer it has a high positive predictive value. When an imaging modality does not localizes the tumour, multi gland disease should be suspected. 


\section{References:}

1. Silverberg SJ, Bilezikian JP. Evaluation and management of primary hyperparathyroidism. J Clin Endocrinol Metab [Internet]. 1996 Jun 1;81(6):2036-40. Available from: http://dx.doi.org/10.1210/jcem.81.6.8964825

2. Wermers RA, Khosla S, Atkinson EJ, Hodgson SF, O'Fallon WM, Melton LJ 3rd. The rise and fall of primary hyperparathyroidism: a population-based study in Rochester, Minnesota, 1965-1992. Ann Intern Med. 1997 Mar;126(6):433-40.

3. Marcocci C, Cetani F. Clinical practice. Primary hyperparathyroidism. N Engl J Med. 2011 Dec;365(25):2389-97.

4. Clifford JR. Pathogenesis and etiology of primary hyperparathyroidism. In: In: UpToDate, Post TW (Ed), UpToDate, Waltham, MA (Accessed on December 26, 2018).

5. John PB. Primary Hyperparathyroidism. In. www.endotext.org, version of January/D12/2017, (25.01.2018), published by MDTEXT.COM,INC, South Dartmouth,MA 02748.

6. Wieneke JA, Smith A. Parathyroid adenoma. Head Neck Pathol [Internet]. 2008/10/22. 2008 Dec;2(4):305-8. Available from: https://www.ncbi.nlm.nih.gov/pubmed/20614300

7. Mundy GR, Cove DH, Fisken R. Primary hyperparathyroidism: changes in the pattern of clinical presentation. Lancet (London, England). 1980 Jun;1(8182):1317-20.

8. Meyer HE, Holvik K, Lofthus CM, Tennakoon SUB. Vitamin D status in Sri Lankans living in Sri Lanka and Norway. Br J Nutr. 2008 May;99(5):941-4. 